\title{
Impacts of long-term fertilization on salt marsh tidal creek benthic nutrient and $\mathrm{N}_{2}$ gas fluxes
}

\author{
Amanda M. Vieillard ${ }^{1, *}$, Robinson W. Fulweiler ${ }^{1,2}$ \\ ${ }^{1}$ Department of Earth and Environment and ${ }^{2}$ Department of Biology, Boston University, 675 Commonwealth Avenue, Boston, \\ Massachusetts 02215, USA
}

\begin{abstract}
Salt marsh ecosystems serve as critical nutrient filters by removing reactive nitrogen (N) through denitrification. We examined the influence of long-term fertilization on $\mathrm{N}$ transformation and removal in a salt marsh tidal creek ecosystem fringing the Plum Island Sound estuary in northern Massachusetts, USA. Sediment oxygen demand was within the range of other marsh systems (1271.9 to $7855.0 \mu \mathrm{mol} \mathrm{m}^{-2} \mathrm{~h}^{-1}$ ) and was not significantly different between the fertilized and reference creek. Net $\mathrm{N}_{2}$ fluxes ranged from net $\mathrm{N}$ fixation of $-402.7 \mu \mathrm{mol} \mathrm{N} \mathrm{N}_{2}-\mathrm{N} \mathrm{m}^{-2} \mathrm{~h}^{-1}$ in the reference creek to net denitrification of $524.9 \mu \mathrm{mol} \mathrm{N} \mathrm{N}_{2}-\mathrm{N} \mathrm{m}^{-2} \mathrm{~h}^{-1}$ in the fertilized creek. Net $\mathrm{N}_{2}$ flux and nitrate uptake were significantly higher in the fertilized creek, and in both creeks, net denitrification appeared to be nitrate limited. We calculated rates of dissimilatory nitrate reduction to ammonium (DNRA) and found it to be significantly higher in the fertilized creek, representing 45 and $11 \%$ of the total nitrate uptake in the fertilized and reference creeks, respectively. Additionally, there was a strong relationship between ammonium and nitrite fluxes in both creeks. These results suggest that DNRA may outcompete denitrification at high nitrate concentrations. Increased anthropogenic nutrient loading may therefore have a detrimental effect on the $\mathrm{N}$ removal capacity of salt marsh ecosystems.
\end{abstract}

KEY WORDS: Denitrification $\cdot$ DNRA $\cdot$ Salt marsh ecosystem $\cdot$ Fertilization $\cdot$ Nitrogen loading

\section{INTRODUCTION}

Since the early 1900 s, human activities have more than doubled the amount of reactive nitrogen $(\mathrm{N})$ on Earth, leading to increased $\mathrm{N}$ delivery to estuaries and coastal oceans via riverine transport, direct wastewater treatment discharge, and atmospheric deposition (Nixon et al. 1996, Vitousek et al. 1997). This upswing in $\mathrm{N}$ to coastal systems has caused widespread eutrophication (Smith 2003), resulting in increased incidences of coastal hypoxia (Rabalais et al. 2001, Diaz \& Rosenberg 2008) and harmful algal blooms (Paerl 2002). Despite this heavy N loading to coasts, as much as $75 \%$ of this biologically reactive $\mathrm{N}$ may be removed through denitrification before it reaches the open ocean (Howarth et al. 1996, Peterson et al. 2001). Coastal wetlands, in particular, are very efficient at removing reactive $\mathrm{N}$ (White \& Howes 1994, Hey 2002). For this reason, salt marsh nutrient cycling and $\mathrm{N}$ removal has been studied worldwide, e.g. in Massachusetts, USA (Valiela \& Teal 1979), the United Kingdom (Abd. Aziz \& Nedwell 1986), coastal Louisiana, USA (DeLaune et al. 1989), coastal North Carolina, USA (Thompson et al. 1995), NW France (Bouchard \& Lefeuvre 2000), Venice, Italy (Eriksson et al. 2003), and Portugal (Caçador et al. 2007).

In salt marshes in general, and in older, higher marshes in particular, the majority of marsh area is flooded by tidal water only during the high spring tides. Therefore, these systems rely heavily on internal nutrient cycling, with about half of their nutrients coming from internal regeneration (White \& Howes 1994, Anderson et al. 1997, Teal \& Howes 2000). As a 
result, the dominant form of reactive $\mathrm{N}$ typically found in salt marshes is ammonium $\left(\mathrm{NH}_{4}{ }^{+} ;\right.$Valiela \& Teal 1979). As salt marshes become increasingly influenced by human activity, anthropogenic $\mathrm{N}$ loads to these systems also increase. However, although $\mathrm{NH}_{4}{ }^{+}$is the more common species of $\mathrm{N}$ in marshes, the most efficient way to remove $\mathrm{N}$ is via denitrification; therefore, nitrate $\left(\mathrm{NO}_{3}{ }^{-}\right)$transformation pathways are critical for permanently removing anthropogenic $\mathrm{N}$ from marsh systems (Howes et al. 1996).

Two $\mathrm{NO}_{3}{ }^{-}$transformation processes are most commonly found in salt marshes. The first is denitrification, the process in which $\mathrm{NO}_{3}{ }^{-}$serves as the terminal electron acceptor for oxidizing organic matter in anoxic sediments (Burgin \& Hamilton 2007). Denitrification is a multi-step pathway that transforms $\mathrm{NO}_{3}{ }^{-}$ into inert $\mathrm{N}_{2}$ gas via nitrite $\left(\mathrm{NO}_{2}{ }^{-}\right)$, nitric oxide (NO), and nitrous oxide $\left(\mathrm{N}_{2} \mathrm{O}\right)$, effectively removing $\mathrm{NO}_{3}{ }^{-}$ from the system. Denitrification in salt marsh sediments is largely a coupled process with nitrification because the reactive $\mathrm{N}$ must be in the form of $\mathrm{NO}_{3}{ }^{-}$to be removed from the system as $\mathrm{N}_{2}$. As ambient $\mathrm{NO}_{3}{ }^{-}$ concentrations tend to be low, denitrifiers rely on nitrification to transform readily abundant $\mathrm{NH}_{4}{ }^{+}$to limiting $\mathrm{NO}_{3}{ }^{-}$via $\mathrm{NO}_{2}{ }^{-}$(Valiela \& Teal 1979, Thompson et al. 1995, Hamersley \& Howes 2002, Dollhopf et al. 2005). The second process is dissimilatory nitrate reduction to ammonium (DNRA), a microbially mediated pathway that transforms $\mathrm{NO}_{3}{ }^{-}$into $\mathrm{NH}_{4}{ }^{+}$via either fermentive processes or, more commonly, the oxidation of reduced sulfur (Brunet \& Garcia-Gil 1996, An \& Gardner 2002, Burgin \& Hamilton 2007). Both types of DNRA reduce $\mathrm{NO}_{3}{ }^{-}$to $\mathrm{NH}_{4}{ }^{+}$via $\mathrm{NO}_{2}{ }^{-}$, subsequently keeping reactive $\mathrm{N}$ within the system (Burgin \& Hamilton 2007, Dong et al. 2009). In addition, another process that can influence $\mathrm{NO}_{3}{ }^{-}$in salt marsh sediments is anaerobic ammonium oxidation, or anammox. Anammox is the oxidation of $\mathrm{NH}_{4}{ }^{+}$with $\mathrm{NO}_{2}{ }^{-}$by chemolithoautotrophs under anaerobic conditions to produce $\mathrm{N}_{2}$. As the $\mathrm{NO}_{2}{ }^{-}$is mostly derived from the reduction of $\mathrm{NO}_{3}{ }^{-}$, anammox also contributes to the removal of $\mathrm{NO}_{3}{ }^{-}$from the system (Burgin \& Hamilton 2007).

Rates of denitrification in salt marshes (e.g. Caffrey et al. 2007, Hopkinson \& Giblin 2008) tend to be higher than rates in other coastal sediments (e.g. Seitzinger 1988, Eyre \& Ferguson 2002, Seitzinger et al. 2006, Fulweiler et al. 2007). Recently, DNRA has been found to be an important pathway in salt marsh ecosystems (Hopkinson \& Giblin 2008, KoopJakobsen \& Giblin 2010). To date, anammox is considered to be a much less prevalent pathway in shallow marine ecosystems than denitrification and
DNRA (Dalsgaard et al. 2005). Increased $\mathrm{NO}_{3}{ }^{-}$concentrations have the potential to enhance all of these processes. However, denitrification has been more widely studied and is a much better constrained process than either DNRA or anammox. The rates of these 2 primary $\mathrm{NO}_{3}{ }^{-}$transformation pathways in the marsh (denitrification and DNRA) may depend largely on the availability of $\mathrm{NO}_{3}{ }^{-}$as well as that of labile carbon, reduced sulfur, and sulfide oxidizing bacteria (Christensen et al. 2000, Burgin \& Hamilton 2007). It is the balance between denitrification and DNRA that helps determine, at least in part, whether salt marshes act as sinks of anthropogenic $\mathrm{N}$.

Several studies have looked into the effect of simulated increases in anthropogenic $\mathrm{N}$ on salt marsh $\mathrm{N}$ cycling and have found denitrification to be stimulated by fertilization (e.g. Valiela et al. 1976, Koch et al. 1992, Lee et al. 1997, Hamersley \& Howes 2005, Caffrey et al. 2007, among many others). While these studies typically focus on $\mathrm{N}$ cycling on the marsh platform, salt marshes primarily receive anthropogenic nutrients in their tidal creeks via runoff and groundwater input (Howes et al. 1996). Additionally, while the high marsh only floods with spring tides, the unvegetated sediments in salt marsh tidal creeks flood twice daily. Therefore, these sediments are exposed to this excess $\mathrm{N}$ for much longer periods of time than the rest of the marsh. Consequently, there are increased opportunities for transformation of anthropogenic $\mathrm{N}$ within the tidal creek sediments (Teal \& Howes 2000, Koop-Jakobsen \& Giblin 2010). As a result, these environments have been found to be important contributors to overall salt marsh $\mathrm{N}$ cycling (Kaplan et al. 1979, Abd. Aziz \& Nedwell 1986, Thompson et al. 2000, Eriksson et al. 2003, Hamersley \& Howes 2003, Dollhopf et al. 2005, KoopJakobsen \& Giblin 2010). Salt marsh tidal creeks have often been found to have considerably higher rates of denitrification than any other portion of the vegetated marsh (e.g. Anderson et al. 1997, Thomas \& Christian 2001, Koop-Jakobsen \& Giblin 2010). In fact, although these areas often comprise $<20 \%$ of total marsh area, they may be responsible for as much as $60 \%$ of total marsh denitrification (Kaplan et al. 1979). Additionally, tidal creek sediments are capable of denitrifying the majority of $\mathrm{NO}_{3}{ }^{-}$entering through groundwater (Harvey \& Odum 1999, Teal \& Howes 2000, Tobias et al. 2001). This denitrification capacity gives salt marsh tidal creeks the potential to remove much of the terrestrially derived $\mathrm{N}$ that enters the marsh before it can be exported to coastal receiving waters (Teal \& Howes 2000, Hamersley \& Howes 2003), making these areas important contrib- 
utors to the $\mathrm{N}$ removal ecosystem service that salt marshes provide.

The present study quantified the summer nutrient dynamics within salt marsh tidal creek sediments and their response to fertilization. By taking advantage of a unique site of long-term tidal water fertilization, we evaluated the summer response of salt marsh tidal creeks to increasing $\mathrm{N}$ loads. In addition, we compared these directly measured fluxes with isotope pairing rates measured in the same creeks by Koop-Jakobsen \& Giblin (2010).

\section{MATERIALS AND METHODS}

\section{Study site}

Core and water samples were

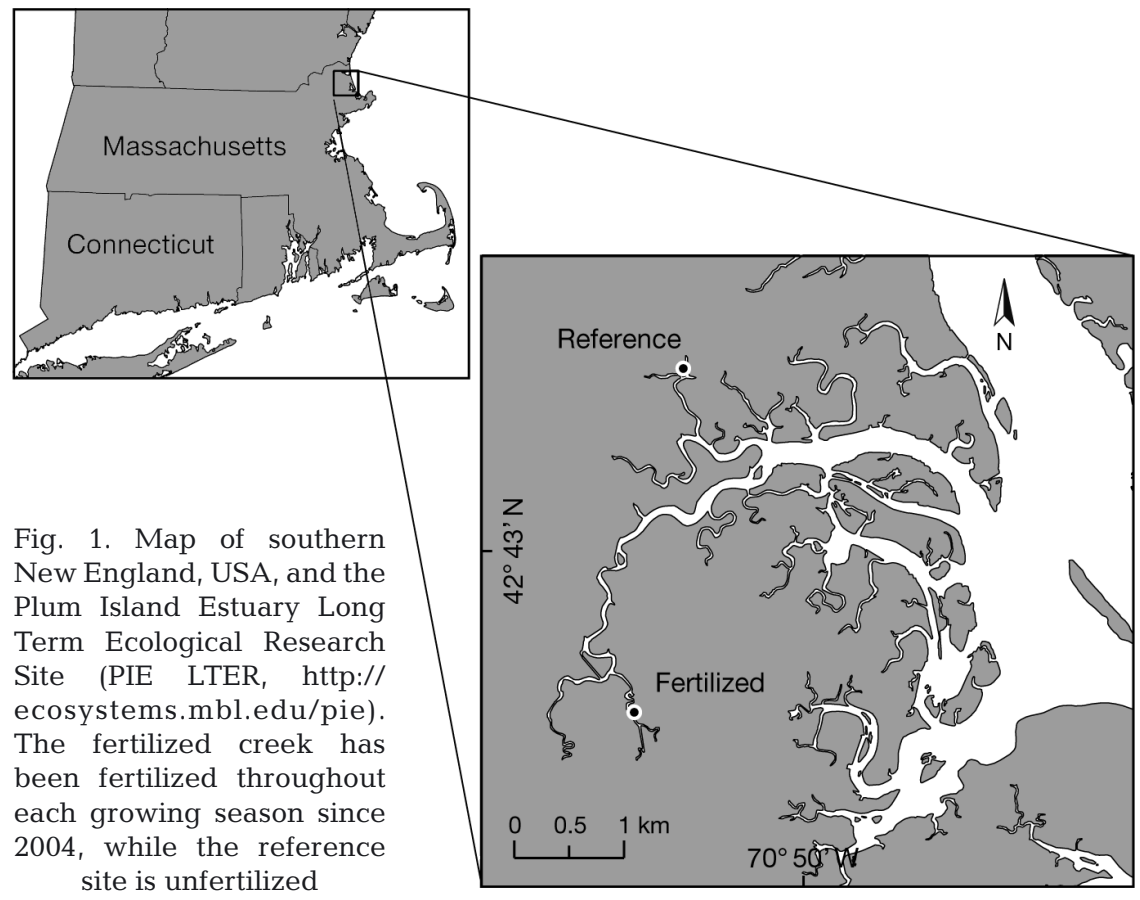
taken from tidal creek beds within the salt marsh system associated with the Plum Island Estuary Long Term Ecological Research Site (PIE LTER, http://ecosystems.mbl.edu/pie) located in Rowley, Massachusetts, USA. This salt marsh system lies on the northeastern Atlantic coast of the USA, connects to the Gulf of Maine through the Plum Island Sound estuary (average salinity $=27.4$ ), and has a total area of $39.8 \mathrm{~km}^{2}$, making it one of the largest salt marsh systems in this region (Buchsbaum et al. 2009). Additionally, the system receives $\sim 89 \times 10^{6} \mathrm{~m}^{3}$ of freshwater input, primarily from the Parker, Rowley, and Ipswich rivers (Buchsbaum et al. 2009). Two different creeks in this system $\left(42^{\circ} 44^{\prime} \mathrm{N}\right.$, $\left.70^{\circ} 50^{\prime} \mathrm{W}\right)-1$ fertilized and 1 reference creekwere sampled in the summers of 2010 and 2011. These creeks experience semi-diurnal tides with an average tidal range of $\sim 3 \mathrm{~m}$ and, despite upstream freshwater input, are entirely tide dominated with virtually no water in the creeks at low tide. One creek has been fertilized from May to September every year since 2004 with $\sim 70 \mu \mathrm{M} \mathrm{NO}_{3}{ }^{-}$(above ambient levels; see Table 2) added directly to the creek water on the incoming tide as part of a longterm fertilization study known as 'trophic cascades and interacting control processes in a detritus-based aquatic ecosystem' (TIDE; Deegan et al. 2007, Johnson et al. 2009). This fertilization influences $\sim 0.2 \mathrm{~km}^{2}$ of marsh annually (Drake et al. 2009). The direct addition of liquid fertilizer to the creek water more accurately mimics the delivery of $\mathrm{N}$ runoff to marshes

than the typical plot-based high marsh fertilization (e.g. Caffrey et al. 2007). Our second site, which had no $\mathrm{NO}_{3}{ }^{-}$fertilizer amendment but is similar in size and hydrological characteristics, served as a reference creek (Fig. 1).

\section{Core sampling}

Triplicate cores were collected on 3 occasions: August 2010, June 2011, and August 2011. Samples of the tidal creek bed were taken by hand using clear polyvinyl chloride cores $(5 \mathrm{~cm}$ diameter $\times 32 \mathrm{~cm}$ tall). The cores were inserted directly into the creek bed sediment at low tide to a depth of $\sim 15 \mathrm{~cm}$, while keeping the sediment surface undisturbed. The cores were then stored in coolers to keep them cool and dark. In the same creeks, water was collected at high tide, filtered to $0.2 \mu \mathrm{m}$, and stored in $20 \mathrm{l}$ carboys. Both cores and filtered site water were transported back to Boston University for incubation, where they were placed in a water bath in an environmental chamber set to ambient creek water temperature.

\section{Whole core incubations}

Cores were left in the water bath overnight with air gently bubbling the overlying water. In the morning, this water was carefully siphoned out and replaced 
with the filtered site water. The cores were filled to the top and then fit with gas-tight lids without any air headspace or bubbles. A magnetic stir bar ( 30 revolutions $\mathrm{min}^{-1}$ ) on the core tops allowed for enough water movement to prevent stratification within the core but not enough to disturb the sediment surface. Cores were incubated in the dark. Replicate water samples were collected in gas-tight $12 \mathrm{ml}$ Exetainer vials (Labco) for later analysis of dissolved $\mathrm{N}_{2}$ and Ar. These samples were taken at 5 time points until the dissolved oxygen in the cores dropped at least $2 \mathrm{mg} \mathrm{l}^{-1}\left(62.5 \mu \mathrm{mol} \mathrm{O}_{2} \mathrm{l}^{-1}\right.$, typically 6 to $\left.8 \mathrm{~h}\right)$. Dissolved oxygen concentrations were measured using a luminescent dissolved oxygen meter (Hach) at each time point. Once the desired drop in oxygen was attained, final samples were taken, and the incubation was stopped before the dissolved oxygen level reached $2 \mathrm{mg} \mathrm{l}^{-1}$ (hypoxia). The caps were then removed from the cores, and the overlying water was gently bubbled with air overnight. The next morning, the water was carefully siphoned off and replaced with filtered site water. Again, we capped the cores with a gas-tight lid and no air headspace for the second incubation for nutrient fluxes. Water samples for nutrient analysis were also collected at 5 time points until the oxygen dropped by at least $2 \mathrm{mg} \mathrm{l}^{-1}$. Samples for $\mathrm{NO}_{3}{ }^{-}, \mathrm{NO}_{2}{ }^{-}, \mathrm{NH}_{4}{ }^{+}$, and dissolved inorganic phosphorus (DIP) analysis were filtered through a $0.7 \mu \mathrm{m}$ glass fiber filter (Whatman GF/F), collected in $30 \mathrm{ml}$ acid washed, polypropylene bottles that had been leached with Milli-Q water, and stored frozen until analysis. At the end of the incubations, we removed sub-samples of sediment from each core (down to $1 \mathrm{~cm}$ in $0.5 \mathrm{~cm}$ increments) for sediment density, porosity, and chlorophyll a ( $\mathrm{chl} a)$ analysis. These samples were also frozen prior to analysis.

\section{Gas and nutrient analysis}

Water samples were analyzed for dissolved $\mathrm{N}_{2}$ and Ar using the $\mathrm{N}_{2} / \mathrm{Ar}$ technique on a quadrupole membrane inlet mass spectrometer against an airequilibrated, deionized water standard at constant in situ temperature (Kana et al. 1994). This method requires no sample preparation and only a small sample size $(<10 \mathrm{ml})$ and allows rapid sampling (20 to 30 samples $\mathrm{h}^{-1}$ ) with a precision of $<0.03 \%$ for $\mathrm{N}_{2} / \mathrm{Ar}$. This method gives net $\mathrm{N}_{2}$ fluxes only. That is, it is a measurement of total denitrification minus total $\mathrm{N}$ fixation, and specific $\mathrm{N}$ transformation pathways cannot be distinguished. For this reason, positive $\mathrm{N}_{2}$ fluxes indicate net denitrification, while negative fluxes indicate net $\mathrm{N}$ fixation.

Dissolved inorganic nitrogen (DIN) and DIP samples were analyzed colorimetrically on a SEAL Autoanalyzer 3 using standard colorimetric techniques (Strickland \& Parsons 1968, Grasshoff et al. 1983). The practical detection limits of the SEAL Autoanalyzer 3 are $0.247,0.066,0.013$, and $0.005 \mu \mathrm{M}$ for ammonium, nitrate, phosphate $\left(\mathrm{PO}_{4}{ }^{3-}\right)$, and nitrite, respectively (K. Czapla pers. comm.). We also routinely compare our laboratory standards to external standards (OSIL environmental instruments and systems) for each nutrient species; this comparison shows that analysis of each species has a precision of $<4.0 \%$.

\section{Analysis of sediment characteristics}

Frozen sediment samples were thawed, sonicated, and extracted in $25 \mathrm{ml}$ of $90 \%$ acetone overnight (Dalsgaard et al. 2000). Extracted samples were then centrifuged, and $2 \mathrm{ml}$ aliquots were extracted and analyzed for chl $a$ and pheophytin fluorescence (Trilogy Fluorometer, Turner Designs). Sediment density and porosity were determined by drying a known volume of sediment from the top portion of each core (0 to $1 \mathrm{~cm}$, in $0.5 \mathrm{~cm}$ increments) at $\sim 60^{\circ} \mathrm{C}$ until a constant weight was achieved. Sediment density was then measured by water displacement, and porosity was also calculated (Dalsgaard et al. 2000).

\section{Data analysis}

We calculated fluxes from the sediment by running a linear regression through each of the 5 incubation sample points plotted against time. Any flux regressions with an $\mathrm{r}^{2}>0.65$ were considered significant (Prairie 1996). The slope of the linear regression was then multiplied by the volume of overlying water in the core and divided by the core area to arrive at a flux of either dissolved gas or nutrients in $\mu \mathrm{mol}$ $\mathrm{m}^{-2} \mathrm{~h}^{-1}$. Positive flux values indicate a release from the sediment, while negative values signify sediment uptake. Oxygen to $\mathrm{NH}_{4}{ }^{+}(\mathrm{O}: \mathrm{N})$ and $\mathrm{NH}_{4}{ }^{+}$to DIP (N:P) ratios were calculated using the flux values and on a molar basis. We only used positive fluxes, and for DIN, this includes the $\mathrm{NH}_{4}{ }^{+}$flux alone because it was the only positive DIN flux (Teague et al. 1988). All statistical analyses were carried out in R. We used 2 -way analysis of variance to test for significant differences in dissolved nutrient and gas fluxes between creeks and among sample dates $(\alpha=0.05)$. The sig- 

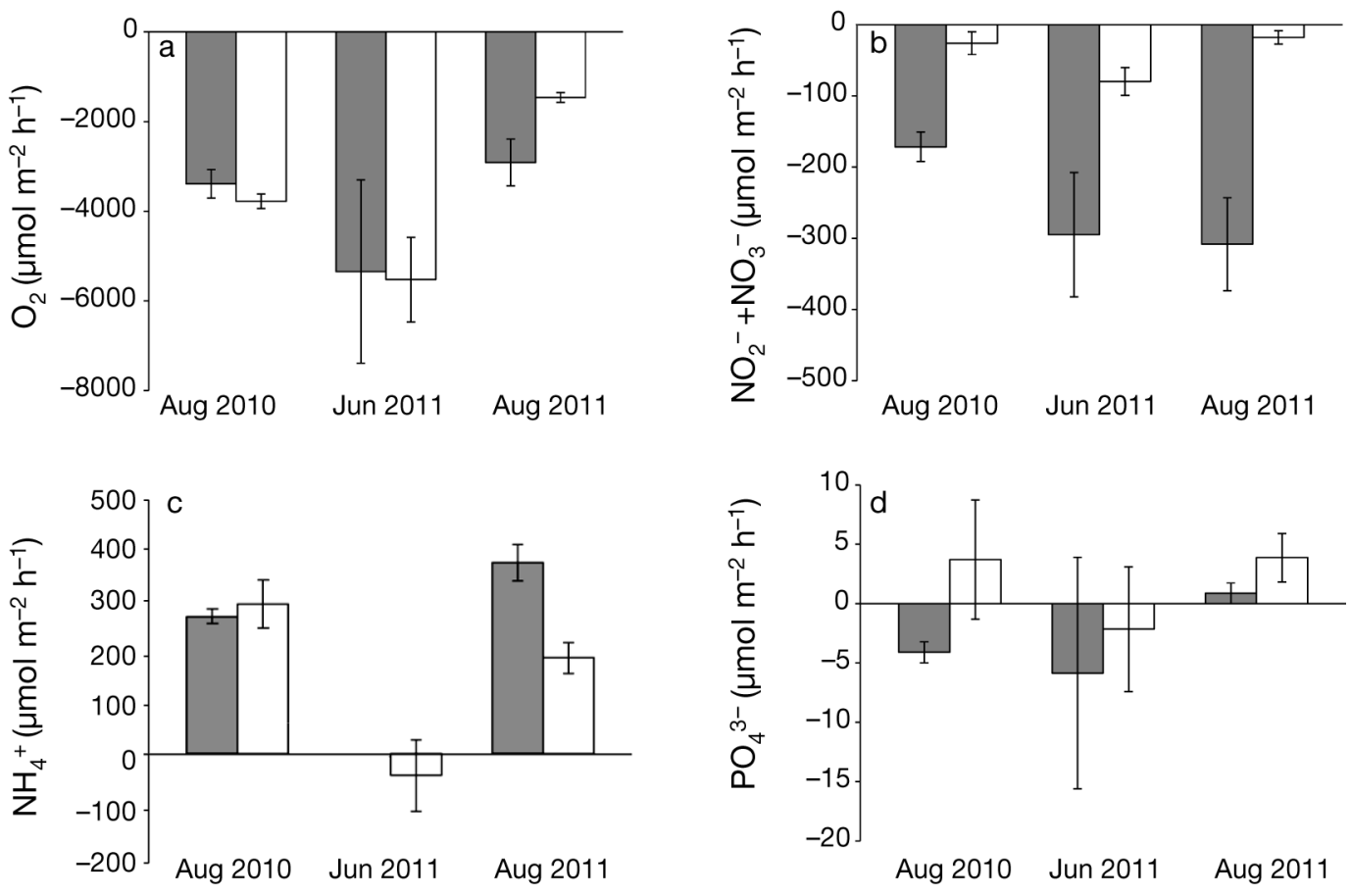

Fig. 2. (a) Sediment oxygen, (b) $\mathrm{NO}_{2}{ }^{-}+\mathrm{NO}_{3}{ }^{-}$, (c) $\mathrm{NH}_{4}{ }^{+}$, and (d) $\mathrm{PO}_{4}{ }^{3-}$ fluxes across the sediment water interface over the course of the present study for the fertilized (shaded bars) and reference creeks (open bars). Positive values indicate release from sediment, while negative values represent sediment uptake. Please note the difference in scale among panels. Mean \pm SE is shown and $\mathrm{n}=9$ for each variable

nificance of each relationship between various nutrient and gas fluxes was calculated using linear regression models, and all errors are reported as standard errors.

\section{RESULTS}

\section{Sediment characteristics}

All of the measured sediment characteristics were very similar between the 2 creeks. There were no significant differences between the fertilized and reference creeks in bulk density, porosity, or chl a content (Table 1). The pheophytin concentration was

Table 1. Sediment bulk density, porosity, chl $a$, and pheophytin values from the top $1 \mathrm{~cm}$ of sediment averaged over all 3 sample dates for each creek. Mean \pm SE is shown $(n=9)$

\begin{tabular}{|lcccc|}
\hline Creek & $\begin{array}{c}\text { Bulk } \\
\text { density }\end{array}$ & Porosity & $\begin{array}{c}\text { Chl a } \\
\left(\mu \mathrm{cm}^{-3}\right)\end{array}$ & $\begin{array}{c}\text { Pheophytin } \\
\left(\mu \mathrm{cm}^{-3}\right)\end{array}$ \\
\hline Fertilized & $1.12 \pm 0.1$ & $0.50 \pm 0.2$ & $1.23 \pm 0.3$ & $2.10 \pm 0.3$ \\
Reference & $1.17 \pm 0.0$ & $0.49 \pm 0.03$ & $1.25 \pm 0.2$ & $1.84 \pm 0.1$ \\
\hline
\end{tabular}

slightly higher in the fertilized creek $(2.1 \pm 0.3$ versus $1.8 \pm 0.1 \mathrm{\mu g} \mathrm{cm}^{-3}$ in the reference, $\mathrm{n}=9$ ), but the difference was not significant. This is surprising as we might expect sediment chl a to be stimulated by fertilization. However, the chl a level was only higher, but not significantly so, in the fertilized creek compared to the reference creek in August $2011(0.9 \pm 0.3$ and $0.5 \pm 0.2 \mu \mathrm{g} \mathrm{cm}^{-3}$, respectively, $\mathrm{n}=9$ ).

\section{Dissolved oxygen}

Sediment oxygen demand (SOD) was lowest in the reference creek in August $2011\left(-1272 \mu \mathrm{mol} \mathrm{m}^{-2} \mathrm{~h}^{-1}\right)$ and greatest in the fertilized creek in June 2011 $\left(-7855 \mu \mathrm{mol} \mathrm{m}^{-2} \mathrm{~h}^{-1}\right)$. There was no significant difference in SOD between the fertilized and reference creeks except in August 2011, when the fertilized creek had significantly more oxygen uptake than the reference creek ( $p=0.05$; Fig. 2a). We also observed no significant difference in oxygen uptake between August 2010 and August 2011. However, in both creeks, SOD was significantly higher in June 2011 than in either of the August sampling events $(\mathrm{p}<$ 0.01; Fig. 2a). 


\section{Dissolved inorganic nutrients}

The fertilized creek had significantly higher $(\mathrm{p}<$ 0.01) ambient concentrations of both $\mathrm{NH}_{4}{ }^{+}$and $\mathrm{NO}_{2}{ }^{-}$ $(30.0 \pm 6$ and $83.2 \pm 13 \mu \mathrm{M}$, respectively, $\mathrm{n}=9)$ than the reference creek $(15.8 \pm 4$ and $5.4 \pm 0.5 \mu \mathrm{M}$, respectively, $\mathrm{n}=9$ ). Both creeks exhibited $\mathrm{NO}_{3}{ }^{-}$ uptake on all sample dates, but rates were signifi-
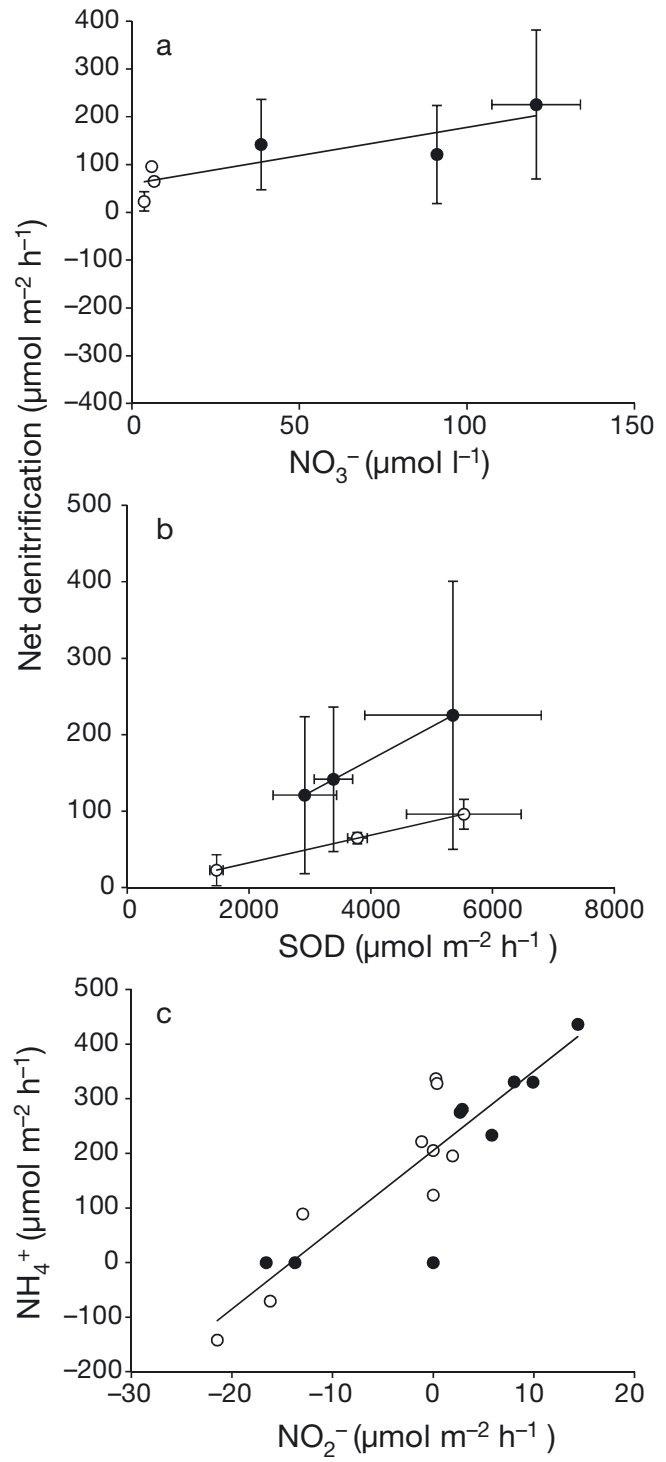

Fig. 3 (a) Net denitrification versus initial water column nitrate concentration $\left(y=1.2 x+59.3, \mathrm{r}^{2}=0.73, \mathrm{p}=0.019\right)$. (b) Average net denitrification versus sediment oxygen demand $(y=0.04 x-3.6, y=0.02 x-3.5$ for fertilized and reference, respectively; $\left(r^{2}=0.99, p<0.01\right.$ for both lines). (c) Ammonium flux versus nitrite flux for both creeks on all 3 sample dates $\left(y=14.5 x+205.2, r^{2}=0.79, p<0.001\right)$. $\bullet$ : fertilized creek values; O: reference creek values. Linear regressions were the best fit for all 3 data sets. Mean $\pm \mathrm{SE}$ is shown, which reflects variability between individual cores ( $a$ and $b$, $\mathrm{n}=3$ ). Please note the difference in scale among panels cantly higher in the fertilized creek $(-258 \pm 43 \mu \mathrm{mol}$ $\left.\mathrm{m}^{-2} \mathrm{~h}^{-1}, \mathrm{n}=9\right)$ than in the reference creek $(-41.2 \pm$ $\left.19 \mu \mathrm{mol} \mathrm{m} \mathrm{m}^{-2} \mathrm{~h}^{-1}, \mathrm{n}=9, \mathrm{p}<0.001\right)$. The highest sediment $\mathrm{NO}_{2}^{-}$uptake was observed in August 2011 (Fig. 2b). $\mathrm{NO}_{2}{ }^{-}$flux was small compared to $\mathrm{NO}_{3}{ }^{-}$flux in both creeks but large when compared with other reported fluxes (Aurand \& Daiber 1973, Gardner \& McCarthy 2009, Chen et al. 2010), with values ranging from -21.5 to $14.4 \mu \mathrm{mol} \mathrm{m} \mathrm{m}^{-2} \mathrm{~h}^{-1}$. Additionally, both creeks showed $\mathrm{NH}_{4}{ }^{+}$efflux in August 2010 and 2011, with no significant difference between fertilized and reference creeks. However, in June 2011, the fertilized creek had a zero $\mathrm{NH}_{4}{ }^{+}$flux, while the reference creek saw $\mathrm{NH}_{4}{ }^{+}$uptake (Fig. 2c). The $\mathrm{NH}_{4}{ }^{+}$ fluxes in both creeks were significantly correlated with $\mathrm{NO}_{2}^{-}$fluxes (Fig. $3 \mathrm{c} ; \mathrm{r}^{2}=0.79, \mathrm{p}<0.001$ ). The $\mathrm{O}: \mathrm{N}$ ratio was not significantly different between the 2 creeks but was higher than predicted by the Redfield ratio (22 and $21 \pm 4$ for the fertilized and reference creeks, respectively, $\mathrm{n}=9$ ).

$\mathrm{PO}_{4}{ }^{3-}$ fluxes in the creeks were quite variable. In August 2010, we observed mean $\mathrm{PO}_{4}{ }^{3-}$ fluxes indicating uptake in the fertilized creek and release in the reference creek $(-4.1 \pm 0.9$ and $3.7 \pm 5.0$, respectively, $n=9$ ). The following summer, there was mean $\mathrm{PO}_{4}{ }^{3-}$ uptake in both creeks in June 2011 and release from both creeks in August 2011 (Fig. 2d). There were no significant differences in $\mathrm{PO}_{4}{ }^{3-}$ flux between the sample dates. On occasions with both positive $\mathrm{NH}_{4}{ }^{+}$and DIP fluxes, the N:P ratio exhibited a large range (15.7 to 198.5$)$, with an average $\mathrm{N}: \mathrm{P}$ ratio of $83.0 \pm 29(\mathrm{n}=6)$.

\section{Dissolved $\mathbf{N}_{2}$}

Net $\mathrm{N}_{2}$ fluxes did not vary significantly between sampling dates (Table 2). However, on average, we observed significantly higher net $\mathrm{N}_{2}$ fluxes in the fertilized creeks compared to the reference (162.7 \pm

Table 2. Initial water column $\mathrm{NO}_{3}{ }^{-}$concentrations and net $\mathrm{N}_{2}$ fluxes for each sample date averaged over triplicate cores in both the fertilized and reference creeks. Mean \pm SE is shown $(\mathrm{n}=3)$

\begin{tabular}{|llcc}
\hline $\begin{array}{l}\text { Sample } \\
\text { date }\end{array}$ & Creek & $\begin{array}{c}{\left[\mathrm{NO}_{3}{ }^{-}\right]} \\
(\mu \mathrm{Mol})\end{array}$ & $\begin{array}{c}\mathrm{N}_{2}-\mathrm{N} \\
\left(\mu \mathrm{mol} \mathrm{N} \mathrm{m}{ }^{-2} \mathrm{~h}^{-1}\right)\end{array}$ \\
\hline Aug 2010 & Fertilized & $38.6 \pm 0.7$ & $141.8 \pm 94.5$ \\
& Reference & $6.7 \pm 0.3$ & $64.9 \pm 7.5$ \\
Jun 2011 & Fertilized & $120.6 \pm 13.0$ & $225.5 \pm 156.0$ \\
& Reference & $5.9 \pm 0.3$ & $-70.2 \pm 175.3$ \\
Aug 2011 & Fertilized & $91.0 \pm 1.0$ & $121.0 \pm 102.5$ \\
& Reference & $3.7 \pm 0.1$ & $7.5 \pm 20.2$ \\
\hline
\end{tabular}


32 and $0.74 \pm 39 \mu \mathrm{mol} \mathrm{N} \mathrm{m}^{-2} \mathrm{~h}^{-1}$, respectively, $\mathrm{n}=9$, $\mathrm{p}=0.034)$. All creeks exhibited net denitrification overall except the reference creek in June 2011, which showed a net $\mathrm{N}$ flux of $-70.2 \pm 175 \mu \mathrm{mol} \mathrm{N}_{2}-\mathrm{N}$ $\mathrm{m}^{-2} \mathrm{~h}^{-1}(\mathrm{n}=3)$. This mean negative rate was driven by very high rates of $\mathrm{N}_{2}-\mathrm{N}$ fixation in one of the 3 June cores, which had a net $\mathrm{N}_{2}$ flux of $-400.3 \mu \mathrm{mol} \mathrm{N}_{2}-\mathrm{N}$ $\mathrm{m}^{-2} \mathrm{~h}^{-1}$. This was one of 2 net $\mathrm{N}$ fixing cores over the course of the present study. On one other occasion, we observed net $\mathrm{N}$ fixation in a sediment core, also from the reference creek, in August 2010 (-23.2 $\mu \mathrm{mol}$ $\mathrm{N}_{2}-\mathrm{N} \mathrm{m}^{-2} \mathrm{~h}^{-1}$ ). Average net denitrification (excluding incidences of net $\mathrm{N}$ fixation, $162.7 \pm 32$ and $61.3 \pm 21$ for fertilized and reference creeks, respectively, $\mathrm{n}=7$ ) varied significantly with average initial water column $\mathrm{NO}_{3}{ }^{-}$concentration in both creeks (Fig. 3a; $\mathrm{r}^{2}=0.73$, $\mathrm{p}=0.019$ ). Net denitrification also varied significantly with average $\mathrm{O}_{2}$ flux in both creeks. However, the slope of this relationship was different for each creek (Fig. 3b; $r^{2}=0.99, p<0.01$ for both lines).

\section{DISCUSSION}

\section{Sediment oxygen demand}

The SOD in the tidal creeks was within the reported range of other salt marsh and tidal creek studies (e.g. Caffrey et al. 2007). The fact that the SOD was similar between the 2 creeks is supported by the similarities in sediment characteristics (Table 1), reassuring us that these creeks are indeed very similar environments. It also indicates that fertilization, at least during these summer months, did not have a large influence on rates of oxygen-consuming processes (such as aerobic organic matter decomposition). However, oxygen uptake was significantly higher in both creeks in June 2011 than in either August sampling. This was surprising given that June 2011 had the coolest temperatures of the 3 dates (22 versus $26^{\circ} \mathrm{C}$ ). Since this is a relatively small difference in temperature, the change in SOD was likely driven by other factors. For example, the chl a to pheophytin ratio was highest in June $(0.7 \pm 0.05, \mathrm{n}=3)$ as opposed to August 2010 and 2011 (0.4 \pm 0.09 and $0.5 \pm 0.06$, respectively, $\mathrm{n}=3$ ). This suggests that there was a higher ratio of living to dead microphytobenthos, which, in a dark incubation, could indicate higher oxygen consumption by both autotrophs and heterotrophs (Ferguson et al. 2003). Additionally, the visible redox layer was deepest in both creeks in June, indicating a larger zone of aerobic processes and therefore higher oxygen uptake (Brune et al. 2000).

\section{Benthic nutrient fluxes}

$\mathrm{PO}_{4}{ }^{3-}$ uptake in the fertilized creek was often coupled with $\mathrm{NH}_{4}^{+}$release, indicating that biological processes in these sediments were retaining P. Additionally, though N:P ratios were variable in both creeks, the ratios were high (average 83.0 \pm 29 , $\mathrm{n}=6$ ), indicating that much more $\mathrm{N}$ than $\mathrm{P}$ was being released from the sediment. N:P ratios of benthic fluxes are indications of the nutrient ratios available for primary production, and our observed ratios suggest that $\mathrm{P}$ might be limiting to creek primary production. In addition, the overall high $\mathrm{N}: \mathrm{P}$ ratios and incidences of sediment $\mathrm{PO}_{4}{ }^{3-}$ uptake suggest that heterotrophic processes in these sediments may also have been $\mathrm{P}$ limited. This is consistent with other studies examining the impact of excess $\mathrm{N}$ on salt marsh ecosystems. Specifically, Van Wijnen \& Bakker (1999) and Sundareshwar et al. (2003) found that salt marsh vegetation and sediment microbial communities were $\mathrm{P}$ limited under $\mathrm{N}$ saturating conditions.

\section{$\operatorname{Net} \mathbf{N}_{2}$}

The net $\mathrm{N}_{2}$ fluxes in the fertilized creek were higher than those reported from British salt marsh tidal creek studies, while those in the reference creek were within the reported range (Abd. Aziz \& Nedwell 1986, Koch et al. 1992). Additionally, our fertilized creek rates were within the reported range of other New England studies (Kaplan et al. 1979, Koop-Jakobsen \& Giblin 2010) as well as an Italian study (Eriksson et al. 2003). However, our rates were a great deal lower than those reported in tidal creek sediments on the Georgia coast, USA (3517 $\mu \mathrm{mol} \mathrm{N}_{2}$ $\mathrm{N} \mathrm{m}^{-2} \mathrm{~h}^{-1}$; Dollhopf et al. 2005). The difference here is likely due to the high density of bioturbating macrofauna in these marsh systems that have been shown to stimulate coupled nitrification-denitrification (Dollhopf et al. 2005).

Net $\mathrm{N}$ fixation is uncommon but not unheard of in salt marsh sediments and may be an important $\mathrm{N}$ source for $\mathrm{N}$ limited marshes (DeLaune et al. 1989, White \& Howes 1994). Our $\mathrm{N}$ fixation appeared to be linked particularly with the $\mathrm{NH}_{4}{ }^{+}$flux. In June 2011, when $\mathrm{NH}_{4}{ }^{+}$flux was negative in the reference creek, we also saw net $\mathrm{N}$ fixation, and at the same time, the fertilized creek had a zero $\mathrm{NH}_{4}{ }^{+}$flux and its lowest rates of net denitrification (Fig. 2c, Table 2). Additionally, the N:P ratio was lowest in June in the reference creek, with a value of 15.7. Though this is 
almost exactly the Redfield ratio, the fact that it was so much lower than the other sampling dates (more than $5 \times$ lower than our observed average) indicates that in June, microbial activity in these creeks was starved for N. This contrasted with the creeks in August, which had much higher N:P ratios and large effluxes of $\mathrm{NH}_{4}{ }^{+}$(Fig. 2c).

The significantly higher rates of $\mathrm{NO}_{3}{ }^{-}$uptake in the fertilized marsh coincided with higher rates of net denitrification (Fig. 2b, Table 2). As in other salt marsh studies, this increase in $\mathrm{NO}_{3}{ }^{-}$uptake and in denitrification was driven by the fertilization (e.g. Koch et al. 1992, Lee et al. 1997, Hamersley \& Howes 2005). The initial $\mathrm{NO}_{3}{ }^{-}$concentration in the overlying creek water and rates of net denitrification were highly correlated in both creeks, indicating that denitrification was $\mathrm{NO}_{3}{ }^{-}$limited and that the additional $\mathrm{NO}_{3}{ }^{-}$supply in the fertilized creek was driving higher rates of denitrification (Fig. 3a). Though this was a linear relationship, it would likely shift at very high $\mathrm{NO}_{3}{ }^{-}$concentrations. It has been shown in estuarine sediment that as $\mathrm{N}$ load increases, a smaller percentage of the added DIN gets denitrified (Seitzinger \& Nixon 1985). Though denitrification can be limited or inhibited by factors such as deeper oxygen penetration or sulfide interaction with either nitrifiers or denitrifiers (Sørenson 1978, Joye \& Hollibaugh 1995), SOD was not significantly different between the creeks, indicating that these factors should be relatively equal between the 2 sites. Likely, there would be a certain threshold of $\mathrm{NO}_{3}{ }^{-}$at which denitrification would be limited by some other factor, such as phosphate or organic matter availability in the fertilized creek (Cornwell et al. 1999). At this point, rates of denitrification would not continue to increase but would either plateau despite increasing $\mathrm{N}$ availability or begin to decrease as another, more competitive process for the conditions (such as DNRA) began to dominate, as has been reported in estuaries (Seitzinger \& Nixon 1985). Though we did see this happening in this system (Table 3), the $\mathrm{NO}_{3}{ }^{-}$ concentrations in the creeks were low enough that denitrification still represented a sizable portion of $\mathrm{NO}_{3}{ }^{-}$removal, at rates that were elevated compared to the reference creek.

In addition to being well correlated with $\mathrm{NO}_{3}{ }^{-}$, the rates of net denitrification (excluding net $\mathrm{N}$ fixing cores) in both creeks were highly correlated with SOD, though the slope of the regression was twice as high for the fertilized creek than for the reference $(0.04$ and 0.02 , respectively; Fig. 3b). This relationship is indicative of coupled nitrification-denitrification, while the relationship between net denitrification and $\mathrm{NO}_{3}{ }^{-}$ indicates direct denitrification. Thus, it is likely that both direct denitrification and coupled nitrificationdenitrification are occurring. This has also been found in isotope pairing studies of salt marshes in which both direct and coupled denitrification have been measured together (Hamersley \& Howes 2005, Koop-Jakobsen \& Giblin 2010).

In fact, in 2010, Koop-Jakobsen \& Giblin published an isotope pairing study that was conducted in these same creeks in August 2006. In their study, both direct and coupled denitrification occurred. However, direct denitrification was much more important in the fertilized creek (Koop-Jakobsen \& Giblin 2010). Overall, Koop-Jakobsen \& Giblin (2010) found higher rates of denitrification than those we measured in the fertilized creek $(332.1 \pm 73.5$ and $162.3 \pm$ $32 \mu \mathrm{mol} \mathrm{N} \mathrm{m}{ }^{-2} \mathrm{~h}^{-1}$, respectively, $\mathrm{n}=9$ for the present study) and lower values than ours in the reference creek $\left(20.6 \pm 2.4\right.$ and $61.3 \pm 21 \mu \mathrm{mol} \mathrm{N} \mathrm{m}{ }^{-2} \mathrm{~h}^{-1}$, respectively, $\mathrm{n}=9$; Table 3 ). The difference between denitrification rates in the 2 studies was primarily in the fertilized creek. This is likely a result of the fact that, though we eliminated net $\mathrm{N}$ fixing cores for this comparison, our $\mathrm{N}_{2}$ fluxes also accounted for any cooccurring sediment $\mathrm{N}$ fixation, while the KoopJakobsen \& Giblin (2010) study was a measure of denitrification only. Additionally, although these 2 studies were done in the same creeks at the same time of year, they were $4 \mathrm{yr}$ apart, and differences between our results may also be reflecting natural, annual variability within this system. However, these differences were not statistically significant, and given that different methods were used and measurements were from different years, there was remarkably good agreement between the 2 studies.

Table 3. Denitrification rates, dissimilatory nitrate reduction to ammonium (DNRA) rates, and percentage of total $\mathrm{NO}_{3}{ }^{-}$uptake as DNRA in the fertilized and reference creeks from Koop-Jakobsen \& Giblin (2010) and the present study. For comparison purposes, the denitrification values from the present study are net values and do not include the 2 instances of net fixation. Mean \pm SE is shown ( $\mathrm{n}=9$ for the present study)

\begin{tabular}{|lccc|}
\hline Creek & $\begin{array}{c}\text { Denitrification } \\
\left(\mu \mathrm{mol} \mathrm{N} \mathrm{m} \mathrm{N}^{-2}\right)\end{array}$ & $\begin{array}{c}\text { DNRA } \\
\left(\mu \mathrm{mol} \mathrm{N} \mathrm{m}{ }^{-2} \mathrm{~h}^{-1}\right)\end{array}$ & $\begin{array}{c}\% \text { total } \mathrm{NO}_{3}^{-} \text {up- } \\
\text { take as DNRA }\end{array}$ \\
\hline Koop-Jakobsen \& Giblin (2010) & \\
Fertilized & $332.1 \pm 73.5$ & $307.3 \pm 82.1$ & 48 \\
Reference & $20.6 \pm 2.4$ & $21.7 \pm 3.1$ & 51 \\
Present study & & \\
Fertilized & $162.6 \pm 32$ & $132.0 \pm 43.1$ & 45 \\
Reference & $61.3 \pm 21$ & $7.69 \pm 4.4$ & 11 \\
\hline
\end{tabular}




\section{DNRA}

Denitrification is just one of the $\mathrm{NO}_{3}{ }^{-}$transformation processes that occurs in salt marsh systems, and it cannot account for the entire $\mathrm{NO}_{3}{ }^{-}$flux found in the present study (Fig. 2). This is especially true for the fertilized creek, where the average $\mathrm{NO}_{3}{ }^{-}$flux was $-258.1 \pm 44 \mu \mathrm{mol} \mathrm{N} \mathrm{m}{ }^{-2} \mathrm{~h}^{-1}(\mathrm{n}=9)$, but the average $\mathrm{N}_{2}$ flux was only $162.7 \pm 33 \mu \mathrm{mol} \mathrm{N} \mathrm{N}_{2}-\mathrm{N} \mathrm{m}^{-2} \mathrm{~h}^{-1}(\mathrm{n}=9$ ), leaving nearly $100 \mu \mathrm{mol} \mathrm{N} \mathrm{m} \mathrm{N}^{-2} \mathrm{~h}^{-1}$ unaccounted for. Based on this result and the large efflux of $\mathrm{NH}_{4}{ }^{+}$we observed in August, we hypothesize that this $\mathrm{NO}_{3}{ }^{-}$ went to DNRA in these creeks. DNRA has been found to be an increasingly important $\mathrm{NO}_{3}{ }^{-}$transformation process in marshes (Hopkinson \& Giblin 2008 ); it can account for anywhere from 0 to $60 \%$ of total $\mathrm{NO}_{3}{ }^{-}$reduction (Tobias et al. 2001, Ma \& Aelion 2005, Koop-Jakobsen \& Giblin 2010) and could account for the 'missing' $\mathrm{NO}_{3}{ }^{-}$flux in our creeks.

If we assume that denitrification and DNRA were the dominant $\mathrm{NO}_{3}{ }^{-}$uptake pathways in our creeks, as has been previously shown (Hopkinson \& Giblin 2008), we can calculate potential rates of DNRA by subtracting the denitrification rate from the absolute value of the $\mathrm{NO}_{3}{ }^{-}$uptake rate. In doing this, we assume that any of the cores in which the $\mathrm{N}_{2}$ flux rates were negative ( $\mathrm{N}$ fixing) or less than the magnitude of the $\mathrm{NO}_{3}{ }^{-}$flux had a DNRA rate of zero. By this calculation, we see that the potential rates of DNRA were significantly higher $(p=0.013)$ in the fertilized creek than in the reference creek (132.0 \pm 43 and $7.7 \pm 4 \mu \mathrm{mol} \mathrm{N} \mathrm{m}^{-2} \mathrm{~h}^{-1}$, respectively, $\mathrm{n}=9$; Table 3). Additionally, DNRA represented a larger percentage of the total $\mathrm{NO}_{3}{ }^{-}$uptake than denitrification in the fertilized creek ( $45 \%$ ) versus the reference creek (11\%; Table 3$)$. The limitation of this calculation is that in the $\mathrm{NO}_{3}{ }^{-}$flux, we only measured $\mathrm{NO}_{3}{ }^{-}$ that was taken up from the water column, but we could not account for $\mathrm{NO}_{3}{ }^{-}$that was produced in the sediment by nitrification, making these estimates of DNRA rates conservative, particularly in the reference creek where coupled nitrification-denitrification has been found to be dominant (Koop-Jakobsen \& Giblin 2010).

Our rates of DNRA are calculated rates and are lower, but comparable, to those measured in these same creeks in 2006 by Koop-Jakobsen \& Giblin (2010) $\left(307.3 \pm 82\right.$ and $21.7 \pm 3 \mu \mathrm{mol} \mathrm{N} \mathrm{m} \mathrm{N} \mathrm{h}^{-1}$ in the fertilized and reference creeks, respectively). However, unlike the rates in our study, Koop-Jakobsen \& Giblin (2010) found that the DNRA rates represented relatively equal percentages $(\sim 50 \%)$ of the total $\mathrm{NO}_{3}{ }^{-}$ uptake in both creeks (Table 3$)$. This difference may, again, be due to the fact that our calculated rates of DNRA can only account for direct $\mathrm{NO}_{3}{ }^{-}$uptake and not for that supplied by nitrification. Though nitrification was not found to be a dominant process in the fertilized creek, it was in the reference creek (KoopJakobsen \& Giblin 2010). Therefore, our calculated DNRA rates may be an underestimation, particularly in the reference creek.

Whether measured or calculated, DNRA rates were higher in the fertilized creek in both our study and that of Koop-Jakobsen \& Giblin (2010). Additionally, they were generally higher than rates found in estuarine sediments (Christensen et al. 2000, An \& Gardner 2002). As DNRA is thought to be controlled by labile carbon and sulfide availability as well as that of $\mathrm{NO}_{3}{ }^{-}$, it is not surprising that it is an important pathway in salt marshes (Burgin \& Hamilton 2007, Hopkinson \& Giblin 2008, Koop-Jakobsen \& Giblin 2010). Salt marshes in general, and fertilized creeks like the one in the present study in particular, are ideal places for DNRA to occur. The mostly anoxic sediments of salt marshes are well known hot spots for sulfide production, providing an ideal environment for the chemolithoautotrophs that carry out DNRA through the reduction of $\mathrm{NO}_{3}{ }^{-}$and the subsequent oxidation of reduced sulfur forms, such as hydrogen sulfide (Burgin \& Hamilton 2007).

Additional evidence for DNRA in these creeks comes from the $\mathrm{NO}_{2}{ }^{-}$and $\mathrm{NH}_{4}{ }^{+}$fluxes. We observed a strong correlation $\left(\mathrm{r}^{2}=0.79, \mathrm{p}<0.001\right)$ between the fluxes of $\mathrm{NH}_{4}{ }^{+}$and $\mathrm{NO}_{2}^{-}$(Fig. 3). Although these fluxes were generally larger in the fertilized creek, the regression also fit the unfertilized reference creek (Fig. 3). Measureable fluxes of $\mathrm{NO}_{2}{ }^{-}$in marine sediments are uncommon, and because it is an intermediate for so many $\mathrm{N}$ cycle processes, determining its source can be challenging. However, the strong correlation of $\mathrm{NO}_{2}^{-}$efflux to $\mathrm{NH}_{4}{ }^{+}$efflux indicated that at least the first step of DNRA was occurring at these creeks. The other $\mathrm{N}$ cycle processes that affect $\mathrm{NO}_{2}{ }^{-}$would likely yield a different pattern with $\mathrm{NH}_{4}{ }^{+}$. For example, nitrification consumes $\mathrm{NH}_{4}{ }^{+}$and produces $\mathrm{NO}_{2}{ }^{-}$as an intermediate and would therefore yield a relationship in the opposite direction of the one we observed. Also, anammox consumes both $\mathrm{NO}_{2}{ }^{-}$and $\mathrm{NH}_{4}{ }^{+}$, ultimately producing $\mathrm{N}_{2}$ therefore, we would expect to see a correlation between $\mathrm{NH}_{4}{ }^{+}$ and $\mathrm{NO}_{2}{ }^{-}$uptake, not release. While denitrification can release $\mathrm{NO}_{2}{ }^{-}$as an intermediate in the second step, it does not directly affect $\mathrm{NH}_{4}{ }^{+}$, so we would not expect to see any correlation between $\mathrm{NH}_{4}{ }^{+}$and $\mathrm{NO}_{2}{ }^{-}$with denitrification alone. Finally, it has been proposed that $\mathrm{NO}_{2}^{-}$is an important intermediary 
product of DNRA, particularly when DNRA dominates over denitrification (Rysgaard et al. 1996, An \& Gardner 2002, Dong et al. 2009, Gardner \& McCarthy 2009). In this process, we might then expect to see an efflux of both intermediary $\mathrm{NO}_{2}{ }^{-}$and of $\mathrm{NH}_{4}{ }^{+}$, the end product. This is exactly what we observed in our creeks. The present study is the first time this relationship between $\mathrm{NH}_{4}{ }^{+}$and $\mathrm{NO}_{2}{ }^{-}$has been reported in a salt marsh ecosystem. The tightly correlated relationship between $\mathrm{NO}_{2}{ }^{-}$and $\mathrm{NH}_{4}{ }^{+}$indicates that DNRA was not only present but also was a prevalent $\mathrm{N}$ transformation process in these creeks, which would keep reactive $\mathrm{N}$ cycling within this system.

DNRA also represented a larger percentage of total $\mathrm{NO}_{3}{ }^{-}$transformation than denitrification in the fertilized creek in the present study (Table 3 ). This, again, was likely the result of the fertilization and a difference in biochemistry between denitrification and DNRA. Michaelis-Menten kinetics describe a reaction rate (in this case, DNRA or denitrification) as a function of the substrate concentration (in this case, $\mathrm{NO}_{3}{ }^{-}$). Denitrification and DNRA have been found to have very different values of $K_{\mathrm{m}}$ (the substrate concentration at which the reaction rate is half of the maximum; Dowd \& Riggs 1965). Denitrification has a $K_{\mathrm{m}}$ value ranging from $\sim 5$ to 10 , while that of DNRA ranges from $\sim 100$ to 500 (Jørgensen 1989). Thus, denitrifiers have a higher reaction rate at low $\mathrm{NO}_{3}{ }^{-}$ concentrations than the organisms carrying out DNRA, whereas DNRA has a higher reaction rate than denitrification at high $\mathrm{NO}_{3}^{-}$concentrations. Therefore, DNRA may outcompete denitrification at higher concentrations of $\mathrm{NO}_{3}^{-}$, while lower $\mathrm{NO}_{3}{ }^{-}$ concentrations may favor denitrification (Jørgensen 1989). If this holds true, future anthropogenic nutrient loading may push sediment processes in favor of DNRA over denitrification, as in the fertilized creek studied here, which in turn favors keeping more reactive $\mathrm{N}$ in the system.

\section{CONCLUSIONS}

Salt marshes serve as a buffer between the terrestrial and marine environments and perform the critical ecosystem service of helping to remove excess reactive $\mathrm{N}$ via denitrification before it reaches coastal receiving waters. Increasing anthropogenic nutrient runoff may potentially push these systems toward higher rates of DNRA instead of denitrification. Under this scenario, salt marsh systems would have a reduced $\mathrm{N}$ filtering capacity, and more anthropogenic $\mathrm{N}$ would be exported to coastal receiving waters. We found denitrification rates in the salt marsh tidal creeks to be comparable to those found in vegetated marsh environments (Caffrey et al. 2007). These unvegetated portions of the marsh receive the brunt of anthropogenic nutrient runoff and are exposed to it for much longer time periods than the marsh platform, making them key contributors to overall salt marsh $\mathrm{N}$ removal. As salt marshes provide a key ecosystem function of $\mathrm{N}$ removal, excess $\mathrm{N}$ loading, as stimulated in this long-term tidal creek fertilization, may be altering the functionality of these ecosystems, thereby jeopardizing their ability to affectively remove reactive $\mathrm{N}$ from the biosphere.

Acknowledgements. We gratefully acknowledge the National Science Foundation, which provided funding for this project through a variety of grants. This work is part of a larger collaborative research grant supported by NSF to S. Fagherazzi, R.W.F., and D. Fitzgerald (NSF OCE 0924287) and L. Deegan (NSF OCE 0923689) in Emerging Topics in Biogeochemistry. This work also benefited from an NSFsupported grant to L. Deegan, lead principal investigator of the TIDE project (NSF DEB 0816963). We also greatly appreciate NSF support to the Plum Island Estuary Long Term Ecological Research (LTER) site (NSF OCE 0423565), where this work took place, and are thankful for access to the facilities at the Plum Island LTER site, which made this work possible. We gratefully acknowledge the assistance of K. Morkeski and L. Deegan (Marine Biological Laboratory, Woods Hole). Additionally, we thank A. Banks, K. Czapla, H. Emery, E. Morgan, and R. Schweiker for field and lab support on this project, E. Heiss for help with membrane inlet mass spectrometer training, and J. Carey for help with GIS and Fig. 1. We thank A. Giblin and 3 anonymous reviewers for their helpful comments that have improved this manuscript. Finally, we are grateful to the freeware community for providing 'R.'

\section{LITERATURE CITED}

Abd. Aziz SA, Nedwell DB (1986) The nitrogen-cycle of an East Coast, UK salt marsh. II. Nitrogen fixation, nitrification, denitrification, tidal exchange. Estuar Coast Shelf Sci 22:689-704

An S, Gardner WS (2002) Dissimilatory nitrate reduction to ammonium (DNRA) as a nitrogen link, versus denitrification as a sink in a shallow estuary (Laguna Madre/Baffin Bay, Texas). Mar Ecol Prog Ser 237:41-50

Anderson IC, Tobias CR, Neikirk BB, Wetzel RL (1997) Development of a process-based nitrogen mass balance model for a Virginia (USA) Spartina alterniflora salt marsh: implication for net DIN flux. Mar Ecol Prog Ser 159:13-27

Aurand D, Daiber FC (1973) Nitrate and nitrite in surface waters of two Delaware salt marshes. Chesapeake Sci 14: 105-111

> Bouchard V, Lefeuvre JC (2000) Primary production and macro-detritus dynamics in a European salt marsh: carbon and nitrogen budgets. Aquat Bot 67:23-42 
Brune A, Frenzel P, Cypionka H (2000) Life at the oxicanoxic interface: microbial activities and adaptations. FEMS Microbiol Rev 24:691-710

Brunet RC, Garcia-Gil LJ (1996) Sulfide-induced dissimilatory nitrate reduction to ammonia in anaerobic freshwater sediments. FEMS Microbiol Ecol 21:131-138

Buchsbaum RN, Deegan LA, Horowitz J, Garritt RH, Giblin AE, Ludlam JP, Shull DH (2009) Effects of regular salt marsh haying on marsh plants, algae, invertebrates and birds at Plum Island Sound, Massachusetts. Wetlands Ecol Manag 17:469-487

Burgin AJ, Hamilton SK (2007) Have we overemphasized the role of denitrification in aquatic ecosystems? A review of nitrate removal pathways. Front Ecol Environ 5:89-96

> Caçador I, Costa AL, Vale C (2007) Nitrogen sequestration capacity of two salt marshes from the Tagus estuary. Hydrobiologia 587:137-145

> Caffrey JM, Murrell MC, Wigand C, McKinney R (2007) Effect of nutrient loading on biogeochemical and microbial processes in a New England salt marsh. Biogeochemistry 82:251-264

> Chen H, Yu Z, Yao Q, Mi T, Liu PL (2010) Nutrient concentrations and fluxes in the Changjiang Estuary during summer. Acta Oceanol Sin 29:107-119

Christensen PB, Rysgaard S, Sloth NP, Dalsgaard T, Schwaerter S (2000) Sediment mineralization, nutrient fluxes, denitrification and dissimilatory nitrate reduction to ammonium in an estuarine fjord with sea cage trout farms. Aquat Microb Ecol 21:73-84

Cornwell J, Kemp WM, Kana TM (1999) Denitrification in coastal ecosystems: Methods, environmental controls, and ecosystem level controls, a review. Aquat Ecol 33:41-54

Dalsgaard T (ed), Nielsen LP, Brotas V, Viaroli P and others (2000) Protocol handbook for NICE - nitrogen cycling in estuaries: a project under the EU research programme: marine science and technology (MAST III). National Environmental Research Institute, Silkeborg

> Dalsgaard T, Thamdrup B, Canfield DE (2005) Anaerobic ammonium oxidation (anammox) in the marine environment. Res Microbiol 156:457-464

> Deegan LA, Bowen JL, Drake D, Fleeger JW and others (2007) Susceptibility of salt marshes to nutrient enrichment and predator removal. Ecol Appl 17:S42-S63

$>$ DeLaune RD, Feijtel TC, Patrick WH (1989) Nitrogen flows in Louisiana Gulf Coast salt marsh: spatial considerations. Biogeochemistry 8:25-37

> Diaz RJ, Rosenberg R (2008) Spreading dead zones and consequences for marine ecosystems. Science 321:926-929

Dollhopf SL, Hyun JH, Smith AC, Adams HJ, O'Brien S, Kostka JE (2005) Quantification of ammonia-oxidizing bacteria and factors controlling nitrification in salt marsh sediments. Appl Environ Microbiol 71:240-246

> Dong LF, Smith CJ, Papaspyrou S, Stott A, Osborn AM, Nedwell DB (2009) Changes in benthic denitrification, nitrate ammonification, and anammox process rates and nitrate and nitrate reductase gene abundances along an estuarine nutrient gradient (the Clone estuary, United Kingdom). Appl Environ Microbiol 75:3171-3179

Dowd JE, Riggs DS (1965) A comparison of estimates of Michaelis-Mentin kinetic constants from various linear transformations. J Biol Chem 240:863-869

Drake DC, Peterson BJ, Galvan KA, Deegan LA and others (2009) Salt marsh ecosystem biogeochemical responses to nutrient enrichment: a paired ${ }^{15} \mathrm{~N}$ tracer study. Ecology 90:2535-2546
Eriksson PG, Svensson JM, Carrer GM (2003) Temporal changes and spatial variation of soil oxygen consumption, nitrification and denitrification rates in a tidal salt marsh of the Lagoon of Venice, Italy. Estuar Coast Shelf Sci 58:861-871

Eyre BD, Ferguson AJP (2002) Comparison of carbon production and decomposition, benthic nutrient fluxes and denitrification in seagrass, phytoplankton, benthic microalgae- and macroalgae-dominated warm-temperate Australian lagoons. Mar Ecol Prog Ser 229:43-59

Ferguson AJP, Eyre BD, Gay JM (2003) Organic matter and benthic metabolism in eutrophic sediments along shallow sub-tropical estuaries, northern New South Wales, Australia. Aquat Microb Ecol 33:137-154

Fulweiler RW, Nixon SW, Buckley BA, Granger SL (2007) Reversal of the net dinitrogen gas flux in coastal marine sediments. Nature 448:180-182

Gardner WS, McCarthy MJ (2009) Nitrogen dynamics at the sediment-water interface in shallow, sub-tropical Florida Bay: Why denitrification may decrease with increased eutrophication. Biogeochemistry 95:185-198

Grasshoff K, Ehrhardt M, Kremling K (1983) Methods of seawater analysis, 2nd edn (revised). Wiley-VCH, Weinheim

> Hamersley MR, Howes BL (2002) Control of denitrification in a septage-treating artificial wetland: the dual role of particulate organic carbon. Water Res 36:4415-4427

> Hamersley MR, Howes BL (2003) Contribution of denitrification to nitrogen, carbon, and oxygen cycling in tidal creek sediments of a New England salt marsh. Mar Ecol Prog Ser 262:55-69

Hamersley MR, Howes BL (2005) Coupled nitrificationdenitrification measured in situ in a Spartina alterniflora marsh with a ${ }^{15} \mathrm{NH}_{4}{ }^{+}$tracer. Mar Ecol Prog Ser 299: 123-135

> Harvey JW, Odum WE (1999) The influence of tidal marshes on upland groundwater discharge to estuaries. Biogeochemistry 10:217-236

> Hey DL (2002) Nitrogen farming: harvesting a different crop. Restor Ecol 10:1-10

Hopkinson C, Giblin A (2008) Nitrogen dynamics in salt marsh ecosystems. In: Capone D, Bronk D, Mulholland $\mathrm{D}$, Carpenter E (eds) Nitrogen in the marine environment. Academic Press, London, p 977-1022

Howarth RW, Billen G, Swaney D, Townsend A and others (1996) Regional nitrogen budgets and riverine N \& P fluxes for the drainages to the North Atlantic Ocean: natural and human influences. Biogeochemistry 35:75-139

Howes BL, Weiskel PK, Goehringer DD, Teal JM (1996) Interception of freshwater and nitrogen transport form uplands to coastal waters: the role of saltmarshes. In: Nordstrom KF, Roman CT (eds) Estuarine shores: evolution, environments, and human alterations. Wiley, Chichester, p 287-310

Johnson DS, Fleeger JW, Deegan LA (2009) Large-scale manipulations reveal that top-down and bottom-up controls interact to alter habitat utilization by saltmarsh fauna. Mar Ecol Prog Ser 377:33-41

$>$ Jørgensen KS (1989) Annual pattern of denitrification and nitrate ammonification in estuarine sediment. Appl Environ Microbiol 55:1841-1847

> Joye SB, Hollibaugh JT (1995) Influence of sulfide inhibition of nitrification on nitrogen regeneration in sediments. Science 270:623-625

Kana TM, Darkangelo C, Hunt MD, Oldham JB, Bennett GE, Cornwell JC (1994) Membrane inlet mass spectro- 
meter for rapid high-precision determination of $\mathrm{N}_{2}, \mathrm{O}_{2}$, and $\mathrm{Sr}$ in environmental water samples. Anal Chem 66: 4166-4170

Kaplan W, Valiela I, Teal JM (1979) Denitrification in a saltmarsh ecosystem. Limnol Oceanogr 24:726-734

Koch MS, Maltby E, Oliver GA, Bakker SA (1992) Factors controlling denitrification rates of tidal mudflats and fringing saltmarshes in south-west England. Estuar Coast Shelf Sci 34:471-485

Koop-Jakobsen K, Giblin AE (2010) The effect of increased nitrate loading on nitrate reduction via denitrification and DNRA in salt marsh sediments. Limnol Oceanogr 55: 789-802

Lee RY, Joye SB, Roberts BJ, Valiela I (1997) The release of $\mathrm{N}_{2}$ and $\mathrm{N}_{2} \mathrm{O}$ from salt-marsh sediments subject to different land-derived nitrogen loads. Biol Bull 193:292-293

Ma H, Aelion CM (2005) Ammonium production during microbial nitrate removal in soil microcosms from a developing marsh estuary. Soil Biol Biogeochem 37: 1869-1878

Nixon SW, Ammerman JW, Atkinson LP, Berounsky VM and others (1996) The fate of nitrogen and phosphorus at the land-sea margin of the North Atlantic Ocean. Biogeochemistry 35:141-180

Paerl HW (2002) Connecting atmospheric nitrogen deposition to coastal eutrophication. Environ Sci Technol 36: 323A-326A

Peterson BJ, Wollheim WM, Mulholland PJ, Webster JR and others (2001) Control of nitrogen export from watersheds by headwater streams. Science 292:86-90

Prairie YT (1996) Evaluating the predictive power of regression models. Can J Fish Aquat Sci 53:490-492

Rabalais NN, Turner RE, Wiseman WJ (2001) Hypoxia in the Gulf of Mexico. J Environ Qual 30:320-329

Rysgaard S, Risgaard-Petersen N, Sloth NP (1996) Nitrification, denitrification, and nitrate ammonification in sediments of two coastal lagoons in Southern France. Hydrobiologia 329:133-141

Seitzinger SP (1988) Denitrification in freshwater and coastal marine ecosystems: ecological and geochemical significance. Limnol Oceanogr 33:702-724

Seitzinger SP, Nixon SW (1985) Eutrophication and the rate of denitrification and $\mathrm{N}_{2} \mathrm{O}$ production in coastal marine sediments. Limnol Oceanogr 30:1332-1339

Seitzinger S, Harrison JA, Bohlke JK, Bouwman AF and others (2006) Denitrification across landscapes and waterscapes: a synthesis. Ecol Appl 16:2064-2090
Smith VH (2003) Eutrophication of freshwater and coastal marine ecosystems: a global problem. Environ Sci Pollut Res Int 10:126-139

Sørenson J (1978) Denitrification rates in a marine sediment as measured by the acetylene inhibition technique. Appl Environ Microbiol 36:139-143

Strickland JDH, Parsons TR (1968) A practical handbook of sea water analysis. Bull Fish Res Board Can 167:1-311

> Sundareshwar PV, Morris JT, Koepfler EK, Fornwalt B (2003) Phosphorus limitation of coastal ecosystem processes. Science 299:563-565

> Teague KG, Madden CJ, Day JW Jr (1988) Sediment-water oxygen and nutrient fluxes in a river-dominated estuary. Estuaries 11:1-9

Teal JM, Howes BL (2000) Salt marsh values: retrospection from the end of the century. In: Weinstein MP, Kreeger DA (eds) Concepts and controversies in tidal marsh ecology. Kluwer Academic Publishers, Dordrecht, p 9-19

Thomas CR, Christian RR (2001) Comparison of nitrogen cycling in salt marsh zones related to sea-level rise. Mar Ecol Prog Ser 221:1-16

> Thompson SP, Paerl HW, Go MC (1995) Seasonal patterns of nitrification and denitrification in a natural and a restored salt-marsh. Estuaries 18:399-408

Thompson SP, Piehler MF, Paerl HW (2000) Denitrification in an estuarine headwater creek within an agricultural watershed. J Environ Qual 29:1914-1923

> Tobias CR, Macko SA, Anderson IC, Canuel EA, Harvey JW (2001) Tracking the fate of high concentration groundwater nitrate plume through a fringing marsh: a combined groundwater tracer and in situ isotope enrichment study. Limnol Oceanogr 46:1977-1989

- Valiela I, Teal JM (1979) Nitrogen budget of a salt-marsh ecosystem. Nature 280:652-656

> Valiela I, Teal JM, Persson NY (1976) Production and dynamics of experimentally enriched salt marsh vegetation: belowground biomass. Limnol Oceanogr 21: 245-252

Van Wijnen HJ, Bakker JP (1999) Nitrogen and phosphorus limitation in a coastal barrier salt marsh: the implications for vegetation succession. J Ecol 87:265-272

Vitousek PM, Aber JD, Howarth RW, Likens GE and others (1997) Human alteration of the global nitrogen cycle: sources and consequences. Ecol Appl 7:737-750

> White DS, Howes BL (1994) Long-term ${ }^{15} \mathrm{~N}$-nitrogen retention in the vegetated sediments of a New England salt marsh. Limnol Oceanogr 39:1878-1892

Submitted: April 23, 2012; Accepted: August 15, 2012 Proofs received from author(s): November 20, 2012
Editorial responsibility: Ronald Kiene, Mobile, Alabama, USA 